\title{
Analisis Budaya Organisasi, Pengembangan Karir dan Penilaian Kinerja terhadap Kepuasan Kerja Karyawan PT Aksara Solopos Surakarta
}

\author{
Laras Cahya Utami ${ }^{1 *)}$, Istiatin ${ }^{2)}$, Djumali $^{3)}$ \\ Fakultas Ekonomi, Program Studi Manajemen, Universitas Islam Batik Surakarta \\ e-mail: larascahyau@gmail.com ${ }^{1 *)}$, istiatinumi@gmail.com ${ }^{2}$, Djumali474@gmail.com ${ }^{3)}$

\begin{abstract}
Abstrak
Tujuan dalam penelitian ini untuk menganalisa adanya pengaruh budaya organisasi, pengembangan karir dan penilaian kinerja terhadap kepuasan kerja karyawan PT Aksara Solopos Surakarta. Populasi berjumlah 185 orang dan diambil sampel 93 responden. Metode pengambilan sampel menggunakan purposive random sampling dengan membagikan kuesioner kepada karyawan PT Aksara Solopos Surakarta. Metode analisis yang digunakan adalah regresi linier berganda. Hasil analisis uji $F$ menunjukkan bahwa budaya organisasi, pengembangan karir dan penilaian kinerja mamiliki pengaruh pada kepuasan kerja karyawan. Hasil analisis secara parsial menunjukkan bahwa variabel pengembangan karir ada pengaruh *pengaruh positif dan signifikan terhadap kepuasan kerja. Sedangkan variabel budaya organisasi tidak ada pengaruh signfikan terhadap kepuasan kerja karyawan.
\end{abstract}

Kata Kunci: budaya organisasi, pengembangan karir, penilaian kinerja, kepuasan kerja

\section{PENDAHULUAN}

Kepuasan kerja karyawan dianggap hal penting sebagai tujuan setiap karyawan. Jika kepuasan kerja rendah maka tingkat kebosanan karyawan juga akan makin tinggi (Arishanti, 2009). Karyawan harus kreatif agar bisa merasa puas. Budaya organisasi dapat mempengaruhi persepsi antar karyawan. Budaya akan membentuk karakter setiap karyawan (Tampubolon et al.,2015). Penerapan budaya organisasi yang baik akan berpengaruh pada kepuasan karyawan. Pengembangan karir dibutuhkan oleh semua karyawan. Hal tersebut bisa memotivasi karyawan supaya bekerja dengan maksimal dan dapat mecapai sebuah kepuasan. Penilaian kinerja dilakukan oleh perusahaan untuk evaluasi terhadap kinerja karyawan. Penilaian kinerja sebagai ukuran prestasi kerja karyawan (Tridayanti, 2015). Hal ini dapat digunakan sebagai tolak ukur kepuasan kerja karyawan. Penilaian yang baik akan meningkatkan kepuasan karyawan.

Berdasarkan uraian diatas maka diambil perumusan masalah: Apakah terdapat pengaruh secara bersama dan secara parsial budaya organisasi, pengembangan karir dan penilaian kinerja pada kepuasan kerja karyawan?. Tujuan dalam penelitian adalah menganalisa adanya pengaruh budaya organisasi, pengembangan karir dan penilaian kinerja terhadap kepuasan kerja karyawan PT. Aksara Solopos Surakarta.

\section{TINJAUAN PUSTAKA}

Menurut Sedarmayanti (2011), kepuasan kerja merupakan sikap umum terhadap pekerjaan seseorang yang menunjukkan perbedaan antara jumlah penghargaan yang diterima pekerja dan jumlah 
yang mereka yakini seharusnya mereka terima. Ivancevich (2006) mendefinisikan budaya organisasi sebagai suatu pola dari asumsi dasar yang diciptakan, ditemukan atau dikembangkan oleh kelompok tertentu saat belajar menghadapi masalah adaptasi eksternal dan integrasi internal yang telah berjalan cukup baik untuk dianggap valid dan oleh karena itu, untuk diajarkan kepada anggota baru sebagai cara yang benar untuk berpersepsi, berpikir dan berperasaan sehubungan dengan masalah yang dihadapi.

Pengertian karir menurut Sinambela (2016) adalah jalan kehidupan pekerjaan seseorang selama hidupnya bekerja. Artinya selama seseorang bekerja akan mengalami perubahan jabatan atau kepangkatan. Sedangkan menurut Kashmir (2016), penilaian kinerja merupakan suatu sistem yang di lakukan secara periodik untuk meninjau dan mengevaluasi kinerja individu.

\section{Kerangka Berpikir}

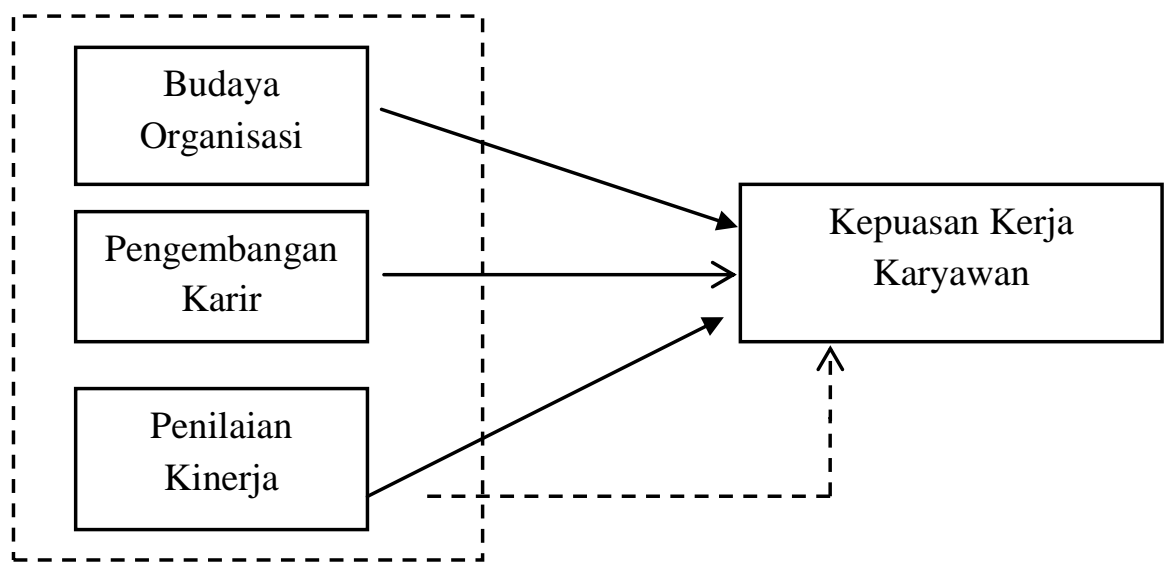

Gambar 1. Kerangka Pemikiran

\section{Hipotesis}

1. Diduga ada pengaruh simultan budaya organisasi, pengembangan karir dan penilaian kinerja pada kepuasan karyawan.

2. Diduga ada pengaruh budaya organisasi pada kepuasan karyawan.

3. Diduga ada pengaruh pengembangan karir pada kepuasan karyawan

4. Diduga ada pengaruh penilaian kinerja pada kepuasan karyawan

\section{METODE PENELITIAN}

1. Jenis, tempat dan waktu

Penelitian ini berupa penelitian kuantitatif yang dilakukan di PT Aksara Solopos Surakarta. Penelitian dilakukan selama dalam kurun waktu 3 bulan.

2. Populasi, sampel dan teknik sampling

Populasi dalam penelitian ini adalah seluruh karyawan PT Aksara Solopos berjumlah 185 orang. 
Sampel yang diambil sebanyak 50\% dari populasi yaitu 93 responden. Teknik yang digunakan teknik sampel acak.

3. Metode analisa data

Analisa yang digunakan uji instrumen, uji asumsi klasik dan pengujian hipotesis (analisis regresi linier berganda, uji F, uji t dan koefisien determinasi).

\section{HASIL DAN PEMBAHASAN}

1. Uji Validitas

Uji validitas dilakukan dengan menyebar 20 kuesioner. Item pernyataan dianggap valid bila $r_{\text {hitung }}>\mathrm{r}_{\text {tabel }}$.

Tabel 1. Hasil Uji Validitas

\begin{tabular}{|c|c|c|c|c|}
\hline Variabel & Item & $r_{\text {hitung }}$ & $r_{\text {tabel }}$ & Keismpulan \\
\hline \multirow{7}{*}{ 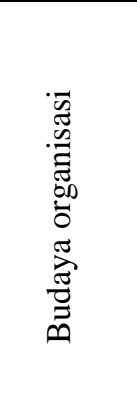 } & 1 & 0.770 & \multirow{7}{*}{0.4438} & \multirow{7}{*}{ VALID } \\
\hline & 2 & 0.725 & & \\
\hline & 3 & 0.656 & & \\
\hline & 4 & 0.444 & & \\
\hline & 5 & 0.717 & & \\
\hline & 6 & 0.731 & & \\
\hline & 7 & 0.553 & & \\
\hline \multirow{5}{*}{ 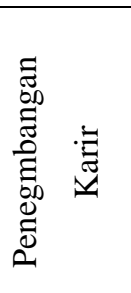 } & 1 & 0.893 & \multirow{5}{*}{0.4438} & \multirow{5}{*}{ VALID } \\
\hline & 2 & 0.807 & & \\
\hline & 3 & 0.940 & & \\
\hline & 4 & 0.869 & & \\
\hline & 5 & 0.813 & & \\
\hline \multirow{5}{*}{ 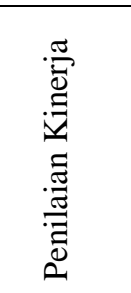 } & 1 & 0.655 & \multirow{5}{*}{0.4438} & \multirow{5}{*}{ VALID } \\
\hline & 2 & 0.837 & & \\
\hline & 3 & 0.766 & & \\
\hline & 4 & 0.875 & & \\
\hline & 5 & 0.533 & & \\
\hline \multirow{5}{*}{ 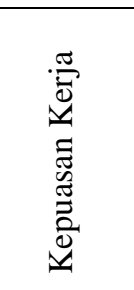 } & 1 & 0.796 & \multirow{5}{*}{0.4438} & \multirow{5}{*}{ VALID } \\
\hline & 2 & 0.825 & & \\
\hline & 3 & 0.496 & & \\
\hline & 4 & 0.883 & & \\
\hline & 5 & 0.749 & & \\
\hline
\end{tabular}

2. Uji Reliabilitas

Item pernyataan dikatakan reliabel jika Alpha lebih besar dari 0,6 
Tabel 2. Hasil Uji Reliabilitas

\begin{tabular}{cccc}
\hline Variabel & $\begin{array}{c}\text { Cronbach's } \\
\text { Alpha }\end{array}$ & $\alpha$ & Ket. \\
\hline Budaya Organisasi & 0,774 & & \\
Pengembangan Karir & 0,913 & 0,6 & Reliabel \\
Penilaian Kinerja & 0,784 & & \\
Kepuasan Kerja & 0,781 & & \\
\hline
\end{tabular}

3. Uji Asumsi Klasik

Uji Normalitas, data dalam penelitian dikatakan normal bila nilai signifikansinya $>\alpha=0,05$. Pengujian normalitas data dalam penelitian ini didapat signifikansi $0,909(0,909>0,05)$, maka data sudah secara normal terdistribusi.

Uji Multikolinieritas, data dikatakan bebas multikolinearitas jika nilai Tolerance melebihi 0,1 dan VIF lebih kecil 10.

Tabel 3. Hasil Uji Asumsi Klasik

\begin{tabular}{lllc}
\hline Variabel & Tolernce & VIF & Ket \\
\hline Budaya Organisai & 0.684 & 1.462 & Tak ada multikolinearitas \\
Pengembangan & 0.521 & 1.919 & Tak ada multikolinearitas \\
karir & & & \\
Penilaian kinerja & 0.419 & 2.388 & Tak ada multikolinearitas \\
\hline
\end{tabular}

4. Uji Heteroskedatisitas

Pengujian heteroskedaktisitas dilakukan dengan pengamatan terhadap penyebaran data pada Scatter plot. Tidak ada pola yang merata dan persebaran titik ada di atas dan bawah angka nol sumbu Y. Maka tak ada heteroskedaktisitas

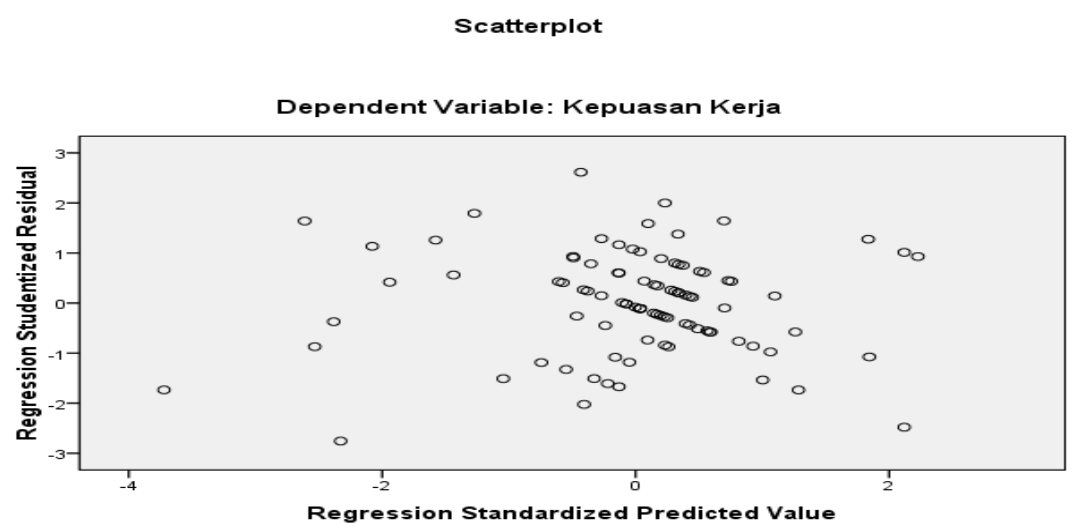

Gambar 2. Scatterplot 


\section{Uji Hipotesis}

1. Analisis Regresi Linier berganda

Tabel 4. Hasil Regresi Linier Berganda

\begin{tabular}{lllr}
\hline & & \multicolumn{2}{c}{ Unstandardized Coefficients } \\
Model & & B & Std. Error \\
\hline 1 & (Constant) & 7.280 & 1.939 \\
& Budaya Organisasi & .080 & .078 \\
& Pengembangan karir & .245 & .084 \\
& Penilaian Kinerja & .289 & .116 \\
\hline
\end{tabular}

Dari tabel diatas didapatkan persamaan sebagai berikut:

$\mathrm{Y}=7,280+0,080 \mathrm{X}_{1}+0,245 \mathrm{X}_{2}+0,289 \mathrm{X}_{3}+\mathrm{e}$

Interpretasi dari persamaan tersebut adalah sebagai berikut:

a. Nilai konstanta sebesar 7,280 menjelaskan jika nilai variabel independen yaitu budaya organisasi, pengembangan karir dan penilaian kinerja 0 (nol) maka nilai kepuasan kerja karyawan adalah 7,280.

b. Nilai koefisien regresi variabel budaya organisasi adalah 0,08. Apabila terjadi kenaikan budaya organisasi sebesar 1, maka kepuasan juga naik sebesar 0,08.

c. Nilai koefisien regresi variabel pengembangan karir adalah 0,245. Apabila terjadi kenaikan pengembangan karir sebesar 1, maka kepuasan juga naik sebesar 0,245.

d. Nilai koefisien regresi variabel penilaian kinerja adalah 0,289. Apabila terjadi kenaikan penilaian sebesar 1, maka kepuasan juga naik sebesar 0,289.

2. Uji F

Tabel 5. Hasil Uji F

\begin{tabular}{llrrrrr}
\hline \multirow{2}{*}{ Model } & & \multicolumn{3}{c}{ Mean } & & \\
& & df & Square & F & Sig. & \\
\hline 1 & Regression & 3 & 66.458 & 21.139 & & $.000^{\mathrm{a}}$ \\
& Residual & 89 & 3.144 & & \\
& Total & 92 & & & \\
& & & & & \\
\hline
\end{tabular}

Hasil uji simultan didapatkan nilai 21,139, maka $F_{\text {hitung }}>F_{\text {tabel }}(21,139>2,71)$. Dapat diambil simpulan secara simultan budaya organisasi, pengembangn karir dan penilaian kinerja berpengaruh terhadap kepuasan kerja. 
3. Uji t

Tabel 6. Hasil Uji t

\begin{tabular}{llll}
\hline Variabel & $\mathrm{t}_{\text {hitung }}$ & $\mathrm{t}_{\text {tabel }}$ & sig \\
\hline Budaya Organisasi & 1.023 & & 0,309 \\
Pengembangan karir & 2.909 & \multirow{2}{*}{1.987} & 0,005 \\
Penilaian Kinerja & 2.498 & & 0,014 \\
\hline
\end{tabular}

a. Pengaruh Budaya organisasi terhadap kepuasan kerja karyawan

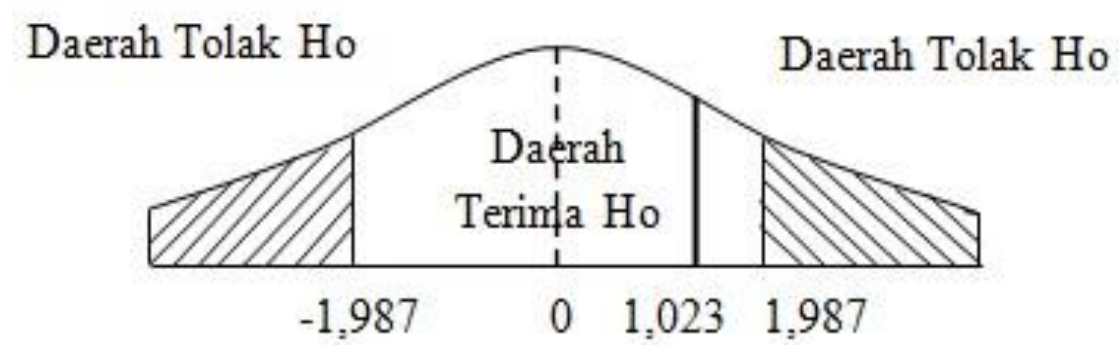

Gambar 3. Uji Hipotesis 2

Penelitian pada variabel budaya organisasi menghasilkan nilai $t_{\text {hitung }}$ sebesar 1,023 , berarti $t_{\text {hitung }}$ $<\mathrm{t}_{\text {tabel }}(1,023<1,987)$ dan signifikansi 0,309 > 0,05. Hal ini berarti hipotesis ditolak

b. Pengaruh pengembangan karir terhadap kepuasan kerja karyawan

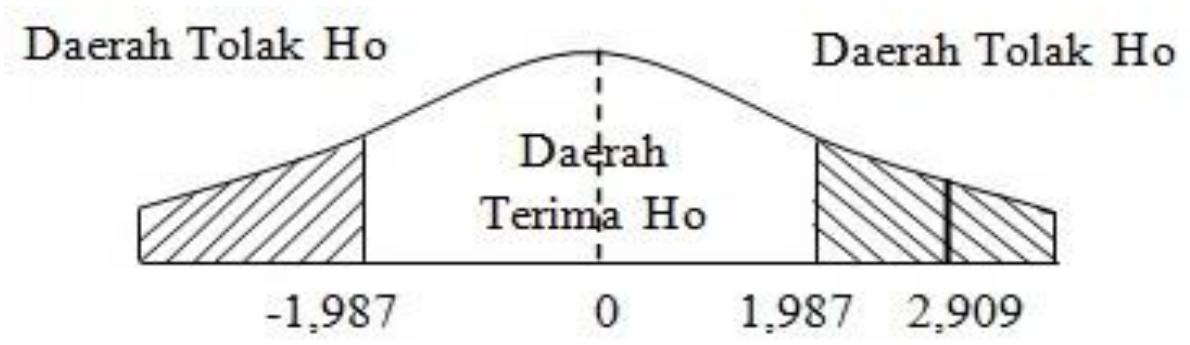

Gambar 4. Uji Hipotesis 3

Penelitian pada variabel pengembangan karir menghasilkan nilai $t_{\text {hitung }} 2,909$, berarti $t_{\text {hitung }}>$ $\mathrm{t}_{\text {tabel }}(2,909>1,987)$ dan signifikansi $0,005<0,05$. Berarti hipotesis diterima.

c. Pengaruh penilaian kinerja terhadap kepuasan kerja karyawan

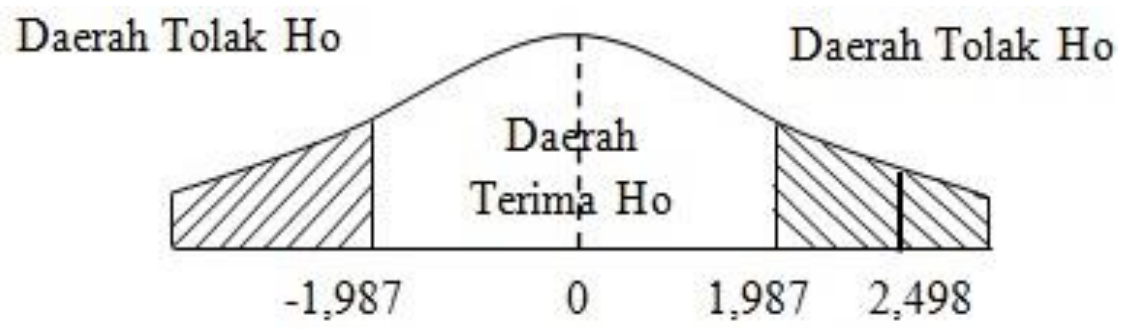

\section{Gambar 5. Uji Hipotesis 4}

Penelitian pada variabel penillaian kinerja menghasilkan nilai $t_{\text {hitung }} 2,498$, berarti $t_{\text {hitung }}>t_{\text {tabel }}$ $(2,498>1,987)$ dan signifikansi $0,014<0,05$. Berarti hipotesis diteima. 
4. Uji Koefisien Determinasi

Tabel 7. Koefisien Determinasi

\begin{tabular}{lrrrr}
\hline & $R$ & Adjusted & & \\
$\mathrm{R}$ & Square & $R$ Square & Std. Error of the Estimate & \\
\hline $.645^{\mathrm{a}}$ & .416 & .396 & & 1.773 \\
\hline
\end{tabular}

Berdasarkan tabel di atas dapat dilihat nilai Adjusted $R$ Square $\left(R^{2}\right)$ sebesar 0,396. Nilai tersebut menunjukkan bahwa kepuasan kerja karyawan dipengaruhi oleh 39,6 \% variabel independen (budaya organisasi, pengembangan karir dan penilaian kinerja), sedangkan 60,4\% sisanya dipengaruhi oleh faktor lain.

\section{Pembahasan}

Hasil dari uji hipotesis pertama menghasilkan $F_{\text {hitung }}>F_{\text {tabel }}(21,139>2,71)$ dan signifikansi $0,00<0,05$. Maka artinya budaya organisasi, pengembangan karir dan penilaian kinerja memiliki pengaruh bersama-sama pada kepuasan kerja karyawan.

Hasil hipotesis kedua dalam penelitian ini dihasilkan koefisien regresi variabel budaya organisasi 0,08 . Sedangkan untuk uji t dihasilkan nilai $t_{\text {hitung }} 1,023<\mathrm{t}_{\text {tabel }} 1,987$ dan signifikansi 0,309. Artinya budaya organiasi tidak memiliki pengaruh signifikan terhadap kepuasan kerja karyawan. Penyebabnya adalah kerjasama tim yang terjadi di PT Aksara Solopos Surakarta belum terjalin dengan baik. Hal tersebut diakibatkan oleh tuntutan pekerjaan yang diharuskan mengoptimalkan hasil kerja, sehingga karyawan tidak merasa nyaman di dalam organisasi dan bekerja secara individual. Maka budaya organisasi yang tercipta tidak berpengaruh terhadap kepuasan kerja karyawan.

Hasil hipotesis ketiga dalam penelitian ini dihasilkan koefisien regresi variabel pengembangan karir 0,245. Sedangkan untuk uji $t$ dihasilkan nilai $t_{\text {hitung }} 2,909>t_{\text {tabel }} 1,987$ dan signifikansi 0,005. Artinya ada pengaruh positif dan signifikan pengembangan karir terhadap kepuasan kerja karyawan. Semakin baik pengembangan karir yang dilakukan maka kepuasan kerja karyawan juga makin tinggi.

Hasil hipotesis keempat dalam penelitian ini dihasilkan koefisien regresi variabel penilaian kinerja 0,289. Sedangkan untuk uji t dihasilkan nilai $t_{\text {hitung }} 2,498>t_{\text {tabel }} 1,987$ dan signifikansi 0,014 . Artinya ada pengaruh positif dan signifikan penilaian kinerja terhadap kepuasan kerja karyawan. Semakin baik penilaian kerja yang dilakukan maka kepuasan kerja karyawan juga makin tinggi.

Sedangkan uji koefisien determinasi dihasilkan angka 0,396 yang artinya budaya organisasi, pengembangan karir dan penilaian kinerja hanya mempengaruhi 39,6\% pada kepuasan kerja karyawan, sedangkan 60,4\% dipengaruhi oleh faktor atau variabel yang tidak masuk dalam penelitian. 


\section{KESIMPULAN DAN SARAN}

\section{Kesimpulan}

1. Budaya organisasi, pengembangan karir dan penilaian kinerja memiliki pengaruh pada kepuasan kerja karyawan secara bersama-sama

2. Budaya organisasi tidak mempunyai pengaruh pada kepuasan kerja karyawan

3. Ada pengaruh positif dan signifikan pengembangan karir pada kepuasan kerja karyawan

4. Ada pengaruh positif dan signifikan penilaian kinerja pada kepuasan kerja karyawan

5. Terdapat pengaruh antara variabel independen pada variabel dependen

\section{Saran}

1. PT Aksara Solopos Surakarta diharapkan memperhatikan budaya organisasi yang ada di dalam perusahaan. Budaya organisasi yang belum terbangun dengan baik tidak berpengaruh pada kepuasan kerja karyawan. Dan juga dapat mengupayakan meningkatkan kerjasama tim antar karyawan.

2. Sebaiknya penilaian kerja serta pengembangan karir harus dipertahankan oleh perusahaan guna meningkatnya kepuasan kerja karyawan serta bisa berdampak meningkatnya kinerja perusahaan.

3. Diharapkan peneliti selanjutnya dapat dimanfaatkan sebagai bahan rujukan dalam melakukan penelitian yang berkaitan dengan budaya organisasi, pengembangan karir dan penilaian kinerja.

\section{REFERENSI}

Arishanti, K. I. 2009. Pengaruh Budaya Organisasi dan Komitmen Organisasional terhadap Kepuasan Kerja Karyawan. Proceeding PESAT (Psikologi, Ekonomi, Sastra, Arsitektur, \& Sipil), 4452.

Kashmir. 2016. Manajemen Sumber Daya Manusia (Teori dan Praktik). Depok: Rajagrafindo Persada.

Sedarmayanti. 2011. Membangun dan Mengembangkan Kepemimpinan serta Meningkatkan Kinerja untuk Meraih Keberhasilan. Bandung: Refika Aditama.

Sinambela, L. P. 2016. Manajemen Sumber Daya Manusia (Membangun Tim Kerja yang Solid untuk Meningkatkan Kinerja). Jakarta: Bumi Aksara.

Tampubolon, E., Purba, V. N., \& Anggraini, N. 2015. Pengaruh Budaya Organisasi dan pengembangan Karir Terhadap Kinerja Karyawan di Kantor Wilayah IV PT POS Indonesia (Persero) Jakarta Pusat. Jurnal Ilmiah, Buletin Ekonomi ISSN: 1410-3842. Vol. 19, No.3. Hal: 42-59. Diakses pada tanggal 16 Desember 2017 Pukul 22.08

Tridayanti, H. 2015. Pengaruh Performance Appraisal dan Turnover Intention Terhadap Kepuasan Kerja pada PT Lucindo Raya Cabang Surabaya Timur. e-Jurnal Spirit Pro Patria. Vol. 1 No. 1, Hal:1-8. http://jurnal.narotama.ac.id/index.php/patria/article/download/43/ diakses pada tanggal 3 Januari 2018 pukul 11.59 WIB 